\title{
Role of a Signalling System in Gene Interaction in Inheritance of Root System Characteristics of Arabidopsis thaliana (L.) Heynh.
}

\author{
Sergei Hablak \\ Lugansk National Agrarian University, Kharkiv, Ukraine \\ Email: serhab211981@yandex.ua
}

How to cite this paper: Hablak, S. (2016) Role of a Signalling System in Gene Interaction in Inheritance of Root System Characteristics of Arabidopsis thaliana (L.) Heynh. Open Journal of Genetics, 6, 51-60.

http://dx.doi.org/10.4236/ojgen.2016.63006

Received: April 10, 2016

Accepted: September 24, 2016

Published: September 27, 2016

Copyright $\odot 2016$ by author and Scientific Research Publishing Inc. This work is licensed under the Creative Commons Attribution International License (CC BY 4.0).

http://creativecommons.org/licenses/by/4.0/

Open Access

\section{Abstract}

The central problem of genetics is gene interaction since genes in the course of individual organism development interact with other genes, that's why their effects may change. Studies for the last 100 years managed to discover that the entire diversity of inter-gene interactions is presented in four major forms: complementarity, epistasis, polymery, and modifying effect of genes. However, gene interaction mechanism which is reflected on the segregation nature of variously crossed hybrids has not been sufficiently studied. Exclusive of molecular genetics, biochemistry and physiology, a genetic analysis of inheritance of characteristics in gene interaction taken by itself cannot reveal nature of this interaction. Lately, molecular-genetic and physiological studies on $A$. thaliana mutants have enabled to isolate and sequence a wide range of genes controlling certain links of the signalling chain. At the same time, effect of the plant development regulation signalling system on interaction of these genes in inheritance of characteristics of Arabidopsis root system haven't been studied so far which was a cause for our studies. Gene interaction problem is closely related to the plant development regulation signalling system. Mechanism involved in gene interaction may be explained based on current idea of molecular principles of biological response. Affected by mutations occurring in various genes that control certain links of the signalling chain, signalling path to the cell nucleus and response are blocked partially or in full which leads to distortion in expression of the characteristic on the plant level in general or its organ level. Such phenomenon is observed in realization of many characteristics in animals and plants, including in $A$. thaliana. In inheritance of such characteristics, as a rule, both allelic, and non-allelic gene interactions are observed. Results of a study of the plant signalling system interconnection and gene interaction in inheritance of characteristics of Arabidopsis root system are presented. It is established that complementary interaction of genes $R H D 3$ and $S A R 1$ is ob- 
served in the second crossing generation for plants of $r h d 3-1 \times$ sar- 1 mutant lines. When gpal-3 $\times$ slr-1 mutant-line plants are crossed, recessive epistasis (slr-1 slr-1 > $G P A 1_{-}$) occurs in $\mathrm{F}_{2}$ generation. Polymeric interaction of genes $S H Y 2$ and $M S G 1$ is observed in $\mathrm{F}_{2}$ in crossing of shy2-2 $\times$ msgl-2 mutant-line plants.

\section{Keywords}

Arabidopsis thaliana (L.) Heynh., Root System, Gene, Mutation, Gene Interaction, Signalling System

\section{Introduction}

The central problem of genetics is gene interaction since genes in the course of individual organism development interact with other genes, that's why their effects may change.

Discovery of gene interaction phenomenon had the most significant importance for the entire further development of genetics. Based on these factors, an idea of an organism as a mosaic of hereditary factors stated in the late 19th century by German Biologist A. Weismann, was discarded. It turned out that the hereditary factor could not be considered as a rudiment of a future characteristic, and genes are not absolutely independent from each other in the organism as it seemed to G. Mendel. Those views were replaced by a statement of a complex connection and interaction between genes in the genotype system in development of any characteristic of an organism [1].

Recently, due to rapidly developing studies of molecular mechanisms of gene expression regulation, it is growing clearer and clearer that manifestation of the most, and, maybe all characteristics of plants and animals in ontogeny result from interaction of multiple genes. And common so-called pleiotropic gene effect residing in an effect of one gene on development of two or more characteristics is determined by complex interactions between genes [2] [3].

Studies for the last 100 years managed to discover that the entire diversity of intergene interactions is presented in four major forms: complementarity, epistasis, polymery, and modifying effect of genes. Each of these forms results in specific changes in known numerical ratios during segregation in dihybrid crossing [4].

However, gene interaction mechanism which is reflected on the segregation nature of variously crossed hybrids has not been sufficiently studied. Exclusive of molecular genetics, biochemistry and physiology, a genetic analysis of inheritance of characteristics in gene interaction taken by itself cannot reveal nature of this interaction.

Recent studies managed to discover that activity of endogenous growth regulators is closely connected with the genetic apparatus function in a plant cell, on the one hand, and with differentiation processes and growth of cells themselves, on the other hand [5]-[7].

Study of interaction between genic and hormonal growth regulation in dwarf mutants of various types of plants has played a significant part in discovery of phytohor- 
mone functions [8]. It has been shown that a chance of every phytohormone formation is regulated by expression of certain genes [9] [10].

So far, some key genes containing promoters sensitive and specific to phytohormones, light and other factors and regulating many important processes and steps of the plant vital functions (photosynthesis, photomorphogenesis, formation of leaves, flowers, nitrogen fixation, embryogenesis, ageing, etc.) have been discovered [2] [11].

Some success has been achieved in study of biosynthesis paths in some classes of photohormones, mechanism of their activity on a molecular level [12]-[15]. Individual genes that control regulatory protein enzymes involved in the cascade regulation mechanism of photohormone synthesis stages have been found using molecular-genetic methods [16] [17].

Signalling paths from photohormones along the chain have been partially studied: receptors-second messengers-specific genes. Signalling interaction mechanisms between various classes of photohormones have been studied in general, their physiological role in regulation of ontogenetic stages of plant development (both embryonic, and postembryonic) has been discovered. Involvement of phytohormones in photomorphogenetic processes, enhancement of plant resistance to unfavourable environmental factors and to pathogens has been revealed [18].

Lately, molecular-genetic and physiological studies on $A$. thaliana mutants have enabled to isolate and sequence a wide range of genes controlling certain links of the signalling chain. They include the following genes SLR1 (SOLITARY-ROOT1), SHY2 (SHORT HYPOCOTIL2), MSG1 (MASSUGU1), SHR1 (SHORT-ROOT1), GPA1 ( G PROTEIN ALPHA SUBUNIT1), RHD3 (ROOT HAIR DEFECTIVE3) and SAR1 (SYNAPTOBREVIN-RELATED PROTEIN1). At the same time, effect of the plant development regulation signalling system on interaction of these genes in inheritance of characteristics of Arabidopsis root system haven't been studied so far which was a cause for our studies.

\section{Materials and Methods}

The study materials were Arabidopsis thaliana (L.) Heynh. plants of Columbia (Co-O) ecotype (race) and mutant lines gpa1-3, rhd3-1, slr-1, shy2-2, shr-1, msg1-2 and sar-1. Seeds of the mutant lines were obtained from Nottingham Arabidopsis Stock Centre (NASC), UK and Arabidopsis Biological Resource Centre (ABRC), USA.

The plants were grown in the laboratory in an aseptic culture in tubes on Knop's agar medium enriched with microelements [19].

Seeds were prepared for planting by means of jarovization for 5 days at $4^{\circ} \mathrm{C}-6^{\circ} \mathrm{C}$ and further one-day germination at room temperature. The tubes were wrapped with two layers of paper to protect from heating and exposure of plant roots to light. The plants were cultivated at $18^{\circ} \mathrm{C}-20^{\circ} \mathrm{C}$, illumination was 24 hours within $4000-7000$ lux.

Castration and forced hybridization were performed under binocular microscope. Genetic analysis of inheritance of plant root system characteristics was conducted in $\mathrm{F}_{1}$, $\mathrm{F}_{2}$ Selection scope in every experiment made up 196 plants. For observation of the 
plants, they followed generally-accepted methods of vegetation and comparative morphological studies (Dospekhov, 1985) [20]. Mathematical processing of results was performed using Statistica software (Borovikov, 2003) [21].

\section{Results and Discussion}

Gene interaction problem is closely related to the plant development regulation signalling system. Mechanism involved in gene interaction may be explained based on current idea of molecular principles of biological response. Genes controlling signalling paths and causing development of a characteristic or a response may be conventionally divided into two large groups:

1) Genes responsible for signal perception and transmission inside the cell;

2) Genes directly ensuring implementation of response to a signal, i.e. so-called primary and secondary response genes.

Genes from the first group encode protein receptors that percept a certain signal of chemical or physical origin, including special proteins (for example, G-proteins, protein kinases, protein phosphatases), some low-molecular compounds included into the cascade system of messenger molecules that transmit the perceived signal into the cell nucleus. Genes from the second group control transcription factors that regulate expression of certain genes, and response to the signal.

Affected by mutations occurring in various genes that control certain links of the signalling chain, signalling path to the cell nucleus and response are blocked partially or in full which leads to distortion in manifestation of the characteristic on the plant level in general or its organ level. Such phenomenon is observed in realization of many characteristics in animals and plants, including in $A$. thaliana. Table 1 presents several genes of Arabidopsis that control a signalling chain of signal transmission into the cell and distortions in manifestation of individual characteristics caused by those mutations.

In inheritance of such characteristics, as a rule, both allelic, and non-allelic gene interactions are observed. The simplest example of allelic gene interaction is complete suppression of expression of a recessive gene of one allelic pair by a dominant geneob

Table 1. A. thaliana genes regulating certain signalling chain links.

\begin{tabular}{|c|c|c|c|c|}
\hline Locus & $\begin{array}{l}\text { Gene product, } \\
\text { reference to a } \\
\text { literary source }\end{array}$ & $\begin{array}{l}\text { Gene product } \\
\text { function }\end{array}$ & Mutation & $\begin{array}{l}\text { Morphological } \\
\text { change }\end{array}$ \\
\hline$G P A 1$ & $\begin{array}{c}\alpha \text {-sub-unit of } \\
\text { G-proteins [22] }\end{array}$ & Signal transmission & Gpal-3 & $\begin{array}{c}\text { Suppression of } \\
\text { secondary root } \\
\text { development }\end{array}$ \\
\hline RHD3 & $\begin{array}{c}\alpha \text {-sub-unit of } \\
\text { G-proteins [25] }\end{array}$ & Signal transmission & Rhd3-1 & $\begin{array}{c}\text { Wavy fibrillas of } \\
\text { epiblema }\end{array}$ \\
\hline $\begin{array}{l}S L R 1, S H Y 2, \\
M S G 1, S H R 1\end{array}$ & $\begin{array}{c}\text { Transcription } \\
\text { factor [19] [20] }\end{array}$ & $\begin{array}{l}\text { Gene expression } \\
\text { regulation }\end{array}$ & $\begin{array}{l}\text { Slr }-1, \text { shy2-2, } \\
m s g 1-1, s h r-1\end{array}$ & $\begin{array}{l}\text { Distortion in root } \\
\text { branching }\end{array}$ \\
\hline$S A R 1$ & $\begin{array}{l}\text { Synaptobrevin } \\
\text { protein [26] }\end{array}$ & $\begin{array}{l}\text { Implementation of } \\
\text { response to the } \\
\text { signal }\end{array}$ & Sar-1 & $\begin{array}{l}\text { Bulb-like root } \\
\text { fibrillas }\end{array}$ \\
\hline
\end{tabular}


served almost in all crossings in the first generation hybrids.

So, for example, in $A$. thaliana, $S H R 1$ gene encodes the transcription factor which controls gene expression in the cell nucleus [22] [23]. Mutation shr-1 of SHR1 gene in plants results in development of fibrous root system characterized by primary root stopping and formation of multiple secondary roots [24]. GPA1 gene is engaged in signal transmission in two-component chemosignal plant systems and encodes alfa subunit of G-proteins [25]. Mutation gpal-3 for GPA1 gene is responsible for suppression of development of secondary roots in plants which leads to formation of taproot [26]. When shr-1 mutant-line plants with fibrous root are crossed with gpal-3 mutant-line plant with a taproot, $\mathrm{F}_{1}$ hybrids form a wild-type-specific mixed root system which results from interaction between genes of two allelic pairs $(s h r-1<S H R 1$, gpal-3 $<G P A 1)$ [27].

Examples of non-allelic interaction in inheritance of such characteristics are epistasis, polymery, complementary and modifying activity of genes. Complementary gene activity in $A$. thalianais observed in inheritance of root fibrilla shape when genes $R H D 3$ and $S A R 1$ interact, when the both supplementary genes are expressed independently.

RHD3 gene encodes $\alpha$-sub-unit of G-proteins (GTP-binding proteins) that transmit a signal from the receptor to effector proteins which stimulates gene transcription and is responsible for the final cellular response [25]. Mutation rhd3-1 of RHD3 gene is responsible for development of wavy fibrillas of epiblema on roots [28]. $S A R 1$ gene is a gene responsible for execution of response to a signal and encodes protein (synaptobrevin) involved, in general, in intracellular vesicles (membrane vesicles) connection with external cell membrane [29]. Mutation sar-1 in $S A R 1$ gene leads to formation of outgrowths of root skin cells enlarged in the upper part (bulb-like) [30].

Tubular (cylindrical) shape of root fibrillas is determined by a homozygous state of $R H D 3$ allele, wavy shape-by $r h d 3-1$ allele. Another allelic pair $S A R 1 S A R 1$ in a homozygous state is responsible for tubular shape of root fibrillas, whereas recessive homozygous state of sar-1 sar-1 gene results in formation of a bulb-like shape of epiblemafibrillas. When two rhd3-1 and sar-1 mutant line plants of Arabidopsis with wavy and bulb-like root fibrillas are crossed, the first generation hybrids $R H D 3$ rhd $3-1 S A R 1$ sar-1 turn out to have cylindrical shape of epiblemafibrillas. Self-pollination of such shapes in the second generation gives segregation of plants by phenotype in the following ratio: 9 with cylindrical shape of root fibrillas: 3 with bulb-like shape of outgrowths of root skin cells: 3 with wavy shape of epiblemafibrillas: 1 with wavy, thickened on top, shape of outgrowths of root surface cells (Table 2).

Despite the fact, that in $\mathrm{F}_{2}$ of this dihybrid crossing, nature of segregation by phenotype is not distorted, however, 1/16 of plants exhibit complementary activity of genes. In $A$. thaliana, joint activity in a genotype of two complementary recessive genes $r h d 3$ 1 and sar-1, every of which by itself may be expressed independently, is responsible for formation of wavy, extended on the top root fibrillas in the second-generation plants. If any of mutant non-allelic genes is absent from the genotype, the new characteristic doesn't develop. 
Table 2. Results of hybridological analysis of $\mathrm{F}_{1}$ and $\mathrm{F}_{2}$ hybrids by the shape of root fibrillas.

\begin{tabular}{|c|c|c|c|c|c|c|}
\hline \multirow{2}{*}{ 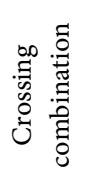 } & \multirow{2}{*}{$\begin{array}{l}\text { Shape of root } \\
\text { fibrillas in } F_{1}\end{array}$} & \multicolumn{2}{|c|}{ Number of plants in $F_{2}$, pcs. } & \multirow{2}{*}{ 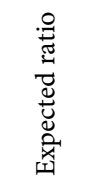 } & \multirow{2}{*}{$\chi^{2}$} & \multirow{2}{*}{$\begin{array}{c}\chi_{s t}^{2}, \\
\mathrm{P}<0.95\end{array}$} \\
\hline & & total & including & & & \\
\hline 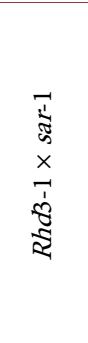 & Cylindrical & 187 & $\begin{array}{l}108 \text { with cylindrical } \\
\text { shape of root } \\
\text { fibrillas, } 33 \text { with } \\
\text { extended on top root } \\
\text { fabrillas, } 36 \text { with } \\
\text { wavy root fabrillas, } \\
10 \text { with wavy } \\
\text { extended on top root } \\
\text { fabrillas }\end{array}$ & $9: 3: 3: 1$ & 0.56 & 7.81 \\
\hline
\end{tabular}

Epistatic activity of genes in Arabidopsisis observed at the example of inheritance of lateral and secondary roots in the root system in interaction of $G P A 1$ and $S L R 1$ genes. $S L R 1$ gene encodes the regulatory protein which controls late-response gene expression [22] [23]. Mutation $s I r-1$ on $S L R 1$ gene causes formation of only the primary root that doesn't branch into lateral roots in plants. $G P A 1$ gene encodes $\alpha$-subunit heterotrimeric GTP-binding proteins (G-proteins) responsible for signal transmission from serpentine receptors to transcription factors [25]. Mutation gpal-3 in this gene in plants is responsible for formation of taproot that has a distinct primary root which is longer and thicker than lateral roots [26].

In $A$. thaliana, recessive allele gpal-3 of GPA1 gene in homozygous state blocks development of secondary roots in the root system, and recessive allele slr-1 of another gene $S L R 1$ also in homozygous state inhibits formation of secondary and lateral roots of the primary root. Crossing of gpal-3 $\times$ slr-1 mutant-line plants gives the first generation hybrids of wild type, i.e. they have lateral roots of the primary root, and secondary roots. In the second generation from $\mathrm{F}_{1}$ hybrid self-pollination, segregation of plants into three phenotype classes is observed in the following ratio: 9/16 with lateral roots of the primary root, and secondary roots (GPA1_SLR1_): 3/16 with lateral roots of the primary root but without secondary roots (gpa1-3 gpa1-3 SLR1_) : 4/16 without lateral roots of the primary root, and secondary roots (GPA1_slr-1 slr-1, gpal-3 gpal-3 slr-1 $s I r-1$ ) (Table 3).

Such behaviour of characteristics in inheritance may be explained by recessive epistasis of $s I r-1$ sIr-1 > GPA1_type when recessive allele of one gene-SLR1 in homozygous state inhibits action of the dominant allele of the other gene-GPA1 in homo-or heterozygous state. And plants of $s I r-1$ sIr-1 GPA1_ genotype turn out to have no lateral roots of the primary root and no secondary roots, just like double homozygous recessive slr-1 slr-1 gpal-3 gpal-3, as recessive gene slr-1 in homozygous state causes formation only of the primary root that doesn't branch into lateral roots thus it prevents dominant gene GPA1 from expressing in homozygous or heterozygous state responsible for development of secondary and lateral roots of the primary root in the 
Table 3. Segregation in $\mathrm{F}_{2}$ generation by genes $G P A 1$ and $S L R 1$.

\begin{tabular}{ccccc}
\hline Identification & $G P A 1_{-} S L R 1_{-}$ & Gpal-3 gpa1-3 SLR1_ & $\begin{array}{c}G P A 1_{-} s l \text {-1 slr-1; } \\
\text { Gpa1-3 gpa1-3 slr-1 slr-1 }\end{array}$ & Total \\
\hline$f$ & 107 & 30 & 45 & 182 \\
$f$ & 102 & 34 & 46 & 182 \\
$d$ & 5 & -4 & -1 & \\
$d^{2}$ & 25 & 16 & 1 & 0.74 \\
$x^{2}$ & 0.25 & 0.47 & 0.02 & \\
\hline
\end{tabular}

root system.

Polymeric activity of genes in $A$. thaliana is observed in inheritance of length of lateral and secondary roots of the primary root in the root system when $S H Y 2$ and $M S G 1$ genes interact. Genes $S H Y 2$ and $M S G 1$ encode the transcription factors which control gene expression in the cell nucleus [22] [23]. Mutations shy2-2, msg1-1 in genes $S H Y 2$, $M S G 1$ are responsible for root branching distortion in the root system [27].

In Arabidopsis, plants of some mutant lines-msg1-2, shy2-2 and others have a reduced degree of root branching determined by several various genes. So, for example, normal length of lateral roots of the primary root is determined by dominant genes $S H Y 2$ and $M S G 1$, and reduced length-by recessive genes shy2-2 and msg1-2. When two plants of shy2-2 and msg1-2 mutant-lines that have reduced, comparing to the wild type, length of different-order lateral roots of the primary root, are crossed, all $\mathrm{F}_{1}$ hybrids (SHY2 shy2-2 MSG1 msg1-2) have a normal length of lateral roots. Self-pollination of such forms in $\mathrm{F}_{2}$ result in that 15/16 of all plants turn out to have varying length of lateral roots of the primary root, and 1/16 have no lateral roots (Table 4).

In this case, two dominant alleles $S H Y 2$ and $M S G 1$ in homozygous or heterozygous state are responsible for the greatest length of lateral roots in the second generation hybrids, while unification of recessive alleles shy2-2 and msg1-2 in homozygous state is responsible for their complete absence. And the length of lateral roots depends on a number of dominant and recessive genes in the genotype. Presence of dominant alleles of two various genes $S H Y 2$ and $M S G 1$ in homozygous or heterozygous state ( $S H Y 2_{-}$ $\left.M S G 1_{-}\right)$is responsible for maximum length of lateral roots in 9/16 of plants. Presence of only the first recessive allele msg1-2 in homozygous state (SHY2_ msg1-2 msg1-2) or only the second recessive allele shy2-2 also in the heterozygous state (shy2-2 shyz-2 $M S G 1_{-}$) is responsible for various interim length of lateral roots in 6/16 of plants. Homozygous state in both recessive genes shy2-2 shy2-2 msg1-2 msg1-2 results in reduction of lateral roots in $1 / 16$ of plants. These results may be explained by a polymeric effect of two other genes $S H Y 2$ and $M S G 1$ on development of the same characteristic "length of lateral roots of the primary root".

Polymeric nature of gene action is widely used in selection and directly related to heterosis. The type of polymeric gene interaction in plants usually determines inheritance of many commercially useful characteristics, such as protein amount in endos perm of corn and wheat grain, sugar content in beet-root, ear length, size of a corn cob, 
Table 4. Segregation in $\mathrm{F}_{2}$ generation by genes $S H Y 2$ and $M S G 1$.

\begin{tabular}{cccc}
\hline Identification & $\begin{array}{l}\text { SHY_ } \\
\text { msg1-2; Shy2-2 shy2-2 MSG1_ }\end{array}$ & $\begin{array}{c}\text { Shy2-2 shy2-2 } \\
\text { msg1-2 msg1-2 }\end{array}$ & Total \\
\hline$f$ & 171 & 15 & 186 \\
$f$ & 174 & 12 & 186 \\
$d$ & -3 & 3 & \\
$d^{2}$ & 9 & 9 & \\
$x^{2}$ & 0.05 & 0.75 & 0.8 \\
\hline
\end{tabular}

content of vitamins in fruits and many others, including length of roots. Being aware of inheritance rules for lateral root length in the root system in gene interaction, one may by crossing, provided initial parental pairs are selected correctly, obtain, from genetic recombination, plants with positive transgressive combination in the same genotype of polymeric genes with additive action, responsible for a higher extent of root branching comparing to the both parental shapes. These plants will be a valuable material in selective programs for creation of agrochemically effective grades and hybrids.

\section{Conclusions}

In general, obtained study results show that the gene interaction mechanism is closely related to current idea of molecular principles of biologic responses. Development of any characteristic, property or reaction to unfavourable environmental conditions in plants is resulted from functioning of many genes that may interact in various ways. Expression regulation of these genes is controlled by endogenous and exogenous signals. They are received by specific receptors and transmitted through mediator molecules on a set of transcription factors suppressing or initiating transcription of certain genes causing the response.

Affected by mutations occurring in various genes controlling certain links of the signalling chain, signalling path to the cell nucleus and the response are blocked partially or in full which leads to distortion in expression of the characteristic on the plant level in general or its organ level. Such phenomenon is observed in realization of many characteristics in animals and plants, including in $A$. thaliana. When such characteristics are inherited, plants display all main forms of gene interaction. Inheritance of lateral and secondary roots in the root system in interaction of genes GPA1 and SLR1 occurs according to the recessive epistasis type ( $\left.s I r-1 s I r-1>G P A 1_{-}\right)$. Polymeric activity of genes $S H Y 2$ and $M S G 1$ is observed in inheritance of length of lateral and secondary roots in the root system. Complementary gene activity is observed in inheritance of root fibrilla shape in interaction of genes RHD3 and $S A R 1$.

\section{References}

[1] Gulyaev, G.V. (1984) Genetics. Kolos, Moscow.

[2] Inge-Vechtomov, S.G. (2000) Genetics of Plant Development. Science, Saint Petersburg. 
[3] Hablak, S.G., Chechenova, T.N. and AbdullaievaIa, A. (2012) Genetic Model in Root System Development in Arabidopsis thaliana (L.) Heynh. Ecology and Nature Protection of Industry-Related Region, 1, 123-130.

[4] Lobashev, M.E. (1985) Genetics. Publishing House of Leningrad State University, Saint Petersburg.

[5] Kefeli, V.I. (1974) Natural Growth Inhibitors and Phitohormones. Nauka, Moscow.

[6] Demkiv, O.T. (1981) Plant Growth and Differentiation. Nauka, Moscow.

[7] Kulaieva, O.N. (1998) Ethylene in Plant Life. Sorosovksy Obrazovatelny Zhurnal, 11, 78-84.

[8] Muromtsev, G.S. and Agnistikova, V.N. (1973) Plant Hormones Gibberellins. Nauka, Moscow.

[9] Shpakov, A.O. (2009) Plant Chemosignal Systems. Cytology, 51, 721-733.

[10] Kulaieva, O.N. (1978) On Gene Expression Regulation in Plant Cells. Physiology of Plants, 25, 990-1008.

[11] Shestakov, S.V. (1998) Molecular Genetics of Photosynthesis. Sorosovksy Obrazovatelny Zhurnal, 9, 22-27.

[12] Kevin, L.-C., Wang, H.L. and Ecker, J.R. (2002) Ethylene Biosynthesis and Signaling Networks. Plant Cell, 14, 131-151.

[13] McCourt, P. (1999) Genetic Analysis of Hormone Signaling. Annual Review of Plant Physiology and Plant Molecular Biology, 50, 219-243.

http://dx.doi.org/10.1146/annurev.arplant.50.1.219

[14] Novikova, G.V., Stepanchenko, N.S., Nosov, A.V. and Moshkov, I.E. (2009) In the Beginning: Abscisic Acid Perception and Signallingin Plants. Physiology of Plants, 56, 806-823.

[15] Romanov, G.A. (2009) How Cytokines Affect a Cell. Physiology of Plants, 56, 295-319.

[16] Romanov, G.A. and Medvedev, S.S. (2006) Auxins and Cytokines in Plant Development. Physiology of Plants, 53, 309-319.

[17] Shemarova, I.V. (2006) Role of Protein Kinase Cascades in Stress Signalling in Inferior Eukaryote Cells. Cytology, 48, 95-113.

[18] Tsigankova, V.A., Galkina, L.A., Musatenko, L.I. and Sytnik, K.M. (2005) Genetic and Epigenetic Plant Growth and Development Control. Auxin Biosynthesis Genes and AuxinRegulated Genes Controlling Plant Cell Division and Extension. Biopolymers \& Cell, 21, 107-133. http://dx.doi.org/10.7124/bc.0006E2

[19] Rubin, B.A., Chernavina, I.A. and Potapov, N.G. (1978) Large Practical Course on Physiology of Plants. Vishay Shkola, Moscow.

[20] Dospekhov, B.A. (1985) Field Experience Method. Agropromizdat, Moscow.

[21] Borovikov, V. (2010) STATISTICA. Arts of Data Analysis on PC: For Professionals, Saint Petersburg, Piter.

[22] Abel, S., Nguyen, D. and Theologis, A. (1995) The PS-1AA415-Like Family of Early AuxinInducible mRNAs in Arabidopsis thaliana. Journal of Molecular Biology, 251, 533-549. http://dx.doi.org/10.1006/jmbi.1995.0454

[23] Helariutta, Y., Fukaki, H., Wysocka-Diller, J., Nakajima, K., Jung, J., Sena, G., Hauser, M.T. and Benfey, P.N. (2010) The SHORT-ROOT Gene Controls Radial Patterning of the Arabidopsis Root through Radial Signaling. Cell, 101, 555-567.

[24] Hablak, S.G. (2013) Effect of SHR1 and SCR1 Genes that Regulate Activity of Root Apical Meristem on Root System Structure in Arabidopsis thaliana (L.) Heynh. Journal of Udmurt University, 1, 46-51. 
[25] Weiss, C.A., Huang, H. and Ma, H. (1993) Immunolocalization of the G Protein Alpha Subunit Encoded by the GPA1 Gene in Arabidopsis. The Plant Cell, 5, 1513-1528.

[26] Hablak, S.G. and AbdullaievaIa, A. (2011) Root System Structure in Mutant Line $g$ Protein alpha subunit1-3 (gpa1-3) Arabidopsis thaliana (L.) Heynh. Ecosystems, Optimization and Protection Thereof, 5, 71-78.

[27] Hablak, S.G. and AbdullaievaIa, A. (2012) Effect of Auxin-Induced Genes on Root Branching in Root System of Arabidopsis thaliana (L.) Heynh. Journal of Kharkiv National Agrarian University, 1, 57-63.

[28] Shan, L., Zhao, S.-Y. and Xia, G.-M. (2008) Cloning of the Full-Length cDNA of the Wheat Involved in Salt Stress: ROOT HAIR DEFECTIVE3 Gene (RHD3). Journal of Integrative Plant Biology, 47, 881-891. http://dx.doi.org/10.1111/j.1744-7909.2005.00090.x

[29] Ono, E., Hatayama, M. and Isono, Y. (2006) Localization of a Flavonoid Biosynthetic Polyphenol Oxidase in Vacuoles. The Plant Journal, 45, 133-143.

http://dx.doi.org/10.1111/j.1365-313X.2005.02625.x

[30] Park, M., Kim, S.J., Vitale, A. and Hwang, I. (2004) Identification of the Protein Storage Vacuole and Protein Targeting to the Vacuole in Leaf Cells of Three Plant Species. Plant Physiology, 134, 625-639. http://dx.doi.org/10.1104/pp.103.030635

Submit or recommend next manuscript to SCIRP and we will provide best service for you:

Accepting pre-submission inquiries through Email, Facebook, LinkedIn, Twitter, etc.

A wide selection of journals (inclusive of 9 subjects, more than 200 journals)

Providing 24-hour high-quality service

User-friendly online submission system

Fair and swift peer-review system

Efficient typesetting and proofreading procedure

Display of the result of downloads and visits, as well as the number of cited articles

Maximum dissemination of your research work

Submit your manuscript at: http://papersubmission.scirp.org/

Or contact ojgen@scirp.org 